\title{
Effects of d-cloprostenol dose and corpus luteum age on ovulation, luteal function, and morphology in nonlactating dairy cows with early corpora lutea
}

\author{
X. Valldecabres-Torres, ${ }^{\star}$ E. García-Roselló,† A. García-Muñoz, ${ }^{*}$ and J. Cuervo-Arango† ${ }^{1}$ \\ *Departamento de Producción y Sanidad Animal, and \\ †Departamento de Medicina y Cirugía Animal, Facultad de Veterinaria, Universidad CEU Cardenal Herrera, 46113 Moncada, Spain
}

\begin{abstract}
Luteolysis is a key event in cattle reproduction. A standard dose of exogenous $\mathrm{PGF}_{2 \alpha}$ will induce full luteolysis in the majority of cows with a matured corpus luteum (CL). However, this will not occur in cows with a $\mathrm{CL}<5 \mathrm{~d}$ old. To date, it is not known whether a larger dose will have a more potent luteolytic effect in cows during early diestrus. The objective of this study was to characterize the effect of 2 doses of d-cloprostenol (150 and $300 \mu \mathrm{g})$ on the progesterone concentration, luteal diameter, and ovulation rate in nonlactating dairy cattle 96 to $132 \mathrm{~h}$ postovulation. Twenty nonlactating dairy cows were included in the study. Each cow received 2 treatments of d-cloprostenol in 2 consecutive cycles: a standard dose of $150 \mu \mathrm{g}$ and a double dose of $300 \mu \mathrm{g}$. The cows were allocated randomly to 1 of 4 groups ( 5 cows in each group) according to the age of the CL at the time of treatment: 96, 108, 120, and $132 \mathrm{~h}$. The exact time of ovulation was known within $12 \mathrm{~h}$, because of twice per day ultrasound examination. The CL diameter and progesterone concentration were measured before treatment (d 0) and 2 and $4 \mathrm{~d}$ after treatment. Within each CL age group, the effect of d-cloprostenol dose on luteolysis was determined. More cows treated with double dose tended to have full luteolysis compared with the standard dose $(8 / 10$ vs. $4 / 10$, respectively). This effect was only apparent in cows with CL of 120 and $132 \mathrm{~h}$ but not in earlier CL. The interval from treatment to ovulation was shorter $(3.3 \pm 0.1 \mathrm{~d})$ in cows treated with a double dose than in cows treated with the standard dose $(4.5 \pm 0.4 \mathrm{~d})$.
\end{abstract}

Key words: cow, progesterone, luteolysis, prostaglandin dose

\section{INTRODUCTION}

The corpus luteum (CL) of cattle is refractory to a single treatment of exogenous native $\mathrm{PGF}_{2 \alpha}(25 \mathrm{mg}$ of

Received December 21, 2011.

Accepted April 11, 2012.

${ }^{1}$ Corresponding author: juan.cuervo@uch.ceu.es dinoprost, manufacturer's recommended dose) within the first $4 \mathrm{~d}$ of the estrous cycle (estrus $=\mathrm{d} 0$; Beal et al., 1980). Even $1 \mathrm{~d}$ later (d 5 of the estrous cycle), a similar dose of $\mathrm{PGF}_{2 \alpha}$ failed to cause full luteolysis in treated heifers and cows (Rowson et al., 1972; Henricks et al., 1974). As a result, most $\mathrm{PGF}_{2 \alpha}$-based protocols of ovulation and estrous synchronization in cattle allow at least a period of $5.5 \mathrm{~d}$ between the previous ovulation and the administration of $\mathrm{PGF}_{2 \alpha}$ (Ovsynch protocol; Pursley et al., 1995) so that the presence of a responsive CL is ensured in cows allocated to these types of protocols. However, a percentage of cows (depending on the study, 5 to $20 \%$ ) fail to undergo full luteolysis following the $\mathrm{PGF}_{2 \alpha}$ treatment of the Ovsynch protocol (Moreira et al., 2000; Gümen et al., 2003; Brusveen et al., 2009).

To study the effect of low progesterone on embryo development, Beltman and coworkers (2009) used a treatment protocol consisting of 3 treatments of luprostiol (15 mg) $12 \mathrm{~h}$ apart, starting on d 3 postestrus in beef heifers (Beltman et al., 2009). By increasing the number of $\mathrm{PGF}_{2 \alpha}$ treatments from single to multiple administrations, an earlier luteolytic response can be obtained. In the latter study (Beltman et al., 2009), most cows underwent partial luteolysis $(67 \%)$ with decreased progesterone concentration, whereas only a few did not respond (22\%) or develop full luteolysis (11\%). Furthermore, an extra $\mathrm{PGF}_{2 \alpha}$ administration $24 \mathrm{~h}$ after the initial $\mathrm{PGF}_{2 \alpha}$ treatment of the Ovsynch protocol increased the percentage of cows with full luteolysis from 85 to $96 \%$ (Brusveen et al., 2009). This phenomenon is relevant to cattle reproduction, as cows with incomplete or partial luteolysis $2 \mathrm{~d}$ after $\mathrm{PGF}_{2 \alpha}$ treatment have reduced chances of becoming pregnant after fixed time AI in an Ovsynch protocol (Souza et al., 2007). Unfortunately, this protocol increases the labor costs, resulting from additional handling of animals required to administer the second $\mathrm{PGF}_{2 \alpha}$ treatment.

In addition to the age of the CL and the frequency of the luteolytic treatment, the dose of the luteolytic agent appears to be a factor that may influence the degree of luteolysis. Evidence shows that full luteolysis is achieved in more mares in early diestrus following a 
single treatment of $500 \mu \mathrm{g}$ of cloprostenol than after a standard dose of $250 \mu \mathrm{g}$ (Cuervo-Arango and Newcombe, 2011). Similarly, the administration of $50 \mathrm{mg}$ of dinoprost to dairy cows 3.5 d postovulation induced full luteolysis in $22 \%$ of treated cows (Cuervo-Arango et al., 2011). Cows with CL of $3.5 \mathrm{~d}$ old are thought to be refractory to a single standard treatment of $\mathrm{PGF}_{2 \alpha}$ (Beal et al., 1980). However, to date no study has compared specifically the dose rate effect of a luteolytic agent on the degree of luteolysis in dairy cattle in early diestrus with different CL ages.

The objective of this study was to characterize the effect of 2 doses of d-cloprostenol (150 and $300 \mu \mathrm{g}$ ) on the progesterone concentration, luteal diameter and ovulation in nonlactating dairy cattle 84 to 132 $\mathrm{h}$ postovulation. The main hypothesis tested was that the larger dose would induce a greater decrease in progesterone concentration and luteal diameter 2 and $4 \mathrm{~d}$ after treatment.

\section{MATERIALS AND METHODS}

\section{Animals}

This trial was conducted from May to June 2011 at the Veterinary School Research Farm of the Universidad CEU Cardenal Herrera in Náquera, Spain (northern hemisphere). All animal procedures were handled in accordance with the Spanish Department of Agriculture Guide for Care and Use of Animals in Research, and they were approved by the Animal Welfare Committee of the Universidad CEU Cardenal Herrera.

A total of 20 nonlactating Holstein cows were used in the trial. The cows had been dry for at least $2 \mathrm{yr}$. The cows' ages ranged from 4 to $10 \mathrm{yr}$ [mean age of $6.7 \pm 1.9$ yr $( \pm \mathrm{SEM})]$. There were 5 nulliparous and 15 multiparous cows. At the beginning of the trial all animals were cyclic and had no apparent uterine or ovarian abnormalities confirmed by ultrasonography. The cows were fed alfalfa hay and cereal concentrate ration calculated for a maintenance diet for dry cows. The mean BCS was $3.5 \pm 0.6$ (range 2.5 to 4 , scale 1 to 5 ) and the mean weight was $645 \pm 47 \mathrm{~kg}$ (range 570 to $680 \mathrm{~kg}$ ). All of the PGF (d-cloprostenol) injections were administered with single-dose syringes in semimembranosus or semitendinosus muscles with 18 -gauge $3.5-\mathrm{cm}$ needles.

\section{Experimental Design}

All cows were administered $25 \mathrm{mg}$ of dinoprost (Enzaprost; CEVA Salud Animal S.A. Barcelona, Spain) 14 $\mathrm{d}$ apart. The day beginning after the second dinoprost administration, the cows were scanned by rectal ultra- sonography every $12 \mathrm{~h}$ for the detection of ovulation with an ultrasound scanner (SonoSite 180 Vet Plus; BCF Ultrasound Australasia, Nunawading, VIC, Australia) equipped with an 8-MHz linear-array transducer. Ovulation was detected as per the disappearance of the previously recorded preovulatory follicle and confirmed by the later development of a CL. Once a cow had ovulated, she was randomly allocated to 1 of the $4 \mathrm{CL}$ age groups: (1) 84 to $96 \mathrm{~h}(\mathrm{n}=5)$, (2) 96 to $108 \mathrm{~h}(\mathrm{n}$ = 5), (3) 108 to $120 \mathrm{~h}(\mathrm{n}=5)$, and (4) 120 to $132 \mathrm{~h}$ $(\mathrm{n}=5)$. For simplicity, the CL age groups are referred to as the oldest possible age (96, 108, 120, and $132 \mathrm{~h}$ ). The study followed a crossover design: for each CL age group, every cow received 2 treatments of d-cloprostenol (Dalmazin; Fatro Ibérica S.L., Barcelona, Spain) during 2 consecutive cycles. The treatments consisted of either a standard dose (recommended by the manufacturer) of $150 \mu \mathrm{g}$ of d-cloprostenol (2 mL of Dalmazin) or a dose of $300 \mu \mathrm{g}$ of d-cloprostenol (4 mL of Dalmazin; double the manufacturer's recommended dose) i.m. For accurate detection of ovulation, after each treatment the cows were scanned every $12 \mathrm{~h}$ until ovulation was detected or until $7 \mathrm{~d}$ later, whatever happened first. If the cow had not ovulated within $7 \mathrm{~d}$ of treatment, she was administered $25 \mathrm{mg}$ of dinoprost, and scanned for detection of ovulation every $12 \mathrm{~h}$. After the consecutive ovulation of the second cycle, each cow received the remaining treatment dose of d-cloprostenol at the same interval postovulation as during the previous cycle and scanned daily for $7 \mathrm{~d}$ to determine CL size. Whether a cow received the standard or the double dose in the first or second cycle was chosen randomly.

For progesterone analysis, a blood sample was taken from the tail vein on each occasion $(0,2$, and $4 \mathrm{~d}$ after treatment), in 5 -mL heparinized tubes. The tubes were immediately centrifuged for $10 \mathrm{~min}$ at $2,000 \times \mathrm{g}$. Aliquots of plasma were stored at $-20^{\circ} \mathrm{C}$ for later assay determination. Concentrations of plasma progesterone were measured in a single assay, using enzyme immunoassay kits (Demeditec Diagnostics GmbH, Kiel-Wellsee, Germany) with a sensitivity of $0.04 \mathrm{ng} / \mathrm{mL}$ and an intraassay variation coefficient of $5 \%$. A cow was classified as having full luteolysis when the progesterone concentration was below $1 \mathrm{ng} / \mathrm{mL} 4 \mathrm{~d}$ posttreatment.

The CL diameter was calculated by the average of 2 measurements taken at right angles with the electronic calipers when the frozen image of the CL was maximum.

\section{Endpoints Analyzed}

The endpoints analyzed were CL diameter and progesterone concentration just before ( $\mathrm{d} 0$ ), and 2 and $4 \mathrm{~d}$ after treatment. And whether the cow ovulated or not 
Table 1. Effect of d-cloprostenol (d-CLO) dose and age of corpus luteum (CL) on ovulation and luteolysis ${ }^{1}$

\begin{tabular}{|c|c|c|c|c|c|c|}
\hline \multirow{2}{*}{$\begin{array}{l}\text { CL age } \\
\text { (h) }\end{array}$} & \multirow{2}{*}{$\begin{array}{l}\text { d-CLO } \\
\text { dose }\end{array}$} & \multicolumn{2}{|c|}{$\begin{array}{l}\% \text { of cows with } \\
\mathrm{P} 4<1 \mathrm{ng} / \mathrm{mL}\end{array}$} & \multicolumn{2}{|c|}{$\begin{array}{l}\text { \% of cows with } \\
\mathrm{P} 4<0.5 \mathrm{ng} / \mathrm{mL}\end{array}$} & \multirow{2}{*}{$\begin{array}{c}\text { Ovulating } \\
\text { cows }\end{array}$} \\
\hline & & $2 \mathrm{~d}$ & $4 \mathrm{~d}$ & $2 \mathrm{~d}$ & $4 \mathrm{~d}$ & \\
\hline \multirow[t]{2}{*}{96} & Standard & 0.0 & 0.0 & 0.0 & 0.0 & $0 / 5$ \\
\hline & Double & 0.0 & 0.0 & 0.0 & 0.0 & $0 / 5$ \\
\hline \multirow[t]{2}{*}{108} & Standard & 0.0 & 0.0 & 0.0 & 0.0 & $0 / 5$ \\
\hline & Double & 20.0 & 20.0 & 0.0 & 20.0 & $0 / 5^{*}$ \\
\hline \multirow[t]{2}{*}{120} & Standard & 20.0 & 20.0 & 0.0 & 20.0 & $1 / 5$ \\
\hline & Double & 40.0 & 60.0 & 40.0 & 60.0 & $2 / 5 \#$ \\
\hline \multirow[t]{2}{*}{132} & Standard & 60.0 & 60.0 & 40.0 & 40.0 & $3 / 5$ \\
\hline & Double & 80.0 & 100.0 & 60.0 & 80.0 & $4 / 5^{*}$ \\
\hline
\end{tabular}

${ }^{1}$ The CL age groups refer to the interval from ovulation to treatment (age of CL). Blood samples were taken 2 and $4 \mathrm{~d}$ after treatment. Double and standard doses are 300 and $150 \mu \mathrm{g}$ of d-cloprostenol, respectively.

*Indicates that a cow developed a luteal cyst with progesterone $(\mathrm{P} 4)$ concentration of $>1 \mathrm{ng} / \mathrm{mL} 7 \mathrm{~d}$ after treatment; \#one cow developed a follicular cyst with $\mathrm{P} 4$ concentration $<1 \mathrm{ng} / \mathrm{mL} 7 \mathrm{~d}$ after treatment.

spontaneously (no treatment to induce ovulation was used in the study) within $7 \mathrm{~d}$ of treatment. If a cystic structure (follicle that never ruptured or collapsed but continued to grow until $>2 \mathrm{~cm}$ in diameter) was present $7 \mathrm{~d}$ posttreatment, an extra blood sample was taken for progesterone determination and cyst classification: a cow with a luteal cyst had progesterone concentration $>1 \mathrm{ng} / \mathrm{mL}$, whereas $<1 \mathrm{ng} / \mathrm{mL}$ with a follicular cyst.

\section{Statistical Analyses}

For each CL age group, a general linear model of variance with a repeated statement to account for autocorrelation between sequential observations of same individuals (Systat 13; Systat Software Inc., Chicago, IL) was performed. Two models were created, one for progesterone concentration and another for CL diameter. Each model had the same 2 fixed factors: dose of d-cloprostenol (2 levels: standard and double dose) and day relative to treatment (repeated observations: on d 0,2 , and 4 after treatment). If an effect of dose (standard vs. double) or an interaction of dose and day were or approached significance, data were examined further by Student's $t$-test.

In cows with full luteolysis, the interval from treatment to ovulation of cows receiving the standard dose was compared with those treated with the double dose by unpaired Student's $t$-test. Frequency data (number of cows with full luteolysis and percentage of ovulating cows) were analyzed by the Fisher exact test.

A probability of $P<0.05$ indicated that a difference was significant and probabilities between $P>0.05$ and $P<0.1$ indicated that a difference approached significance. Data are presented as mean \pm standard error of the mean, unless stated otherwise.

\section{RESULTS}

No cow ovulated in the 2 earliest CL age groups (96 and $108 \mathrm{~h}$ ). However, 1 cow treated with a double dose of d-cloprostenol had full luteolysis, followed by the development of a luteal cyst (Table 1). In these 2 groups, the dose of d-cloprostenol had no effect on the progesterone concentration (Figure 1; $P>0.05$ ). However, the double dose of d-cloprostenol tended to induce a greater decrease in the posttreatment CL diameter in cows treated $108 \mathrm{~h}$ postovulation. In addition, in this group, a significant effect of dose by day interaction on the CL diameter was observed. This resulted from a slower increase 2 and $4 \mathrm{~d}$ posttreatment in the CL diameter of cows treated with the double dose (Figure 1).

In the 2 oldest CL groups (120 and $132 \mathrm{~h}$ ), the double dose of d-cloprostenol tended $(P=0.07)$ to induce full luteolysis in more cows $(8 / 10)$ than the standard dose (4/10; Table 1$)$. Two cows with full luteolysis from the double dose groups did not ovulate but developed cystic ovaries (Table 1). Overall, 4 and 6 cows ovulated after treatment with the standard and double dose of d-cloprostenol, respectively $(P>0.05)$. In these ovulating cows, the interval from treatment to ovulation was shorter $(P<0.05)$ in those treated with double dose $(3.3 \pm 0.1 \mathrm{~d})$ than in cows administered the standard dose $(4.5 \pm 0.4 \mathrm{~d})$.

For the CL age group of $120 \mathrm{~h}$, the double dose of d-cloprostenol tended to induce a greater decrease in the posttreatment progesterone concentration and CL diameter (Figure 1; $P<0.1)$. An effect $(P<0.05)$ of dose by day interaction on the CL diameter was observed. For the oldest CL group (132 h), the double dose induced a greater decrease in the posttreatment progesterone concentration $(P<0.05)$ and CL diameter $(P<0.1$; Figure 1$)$. 

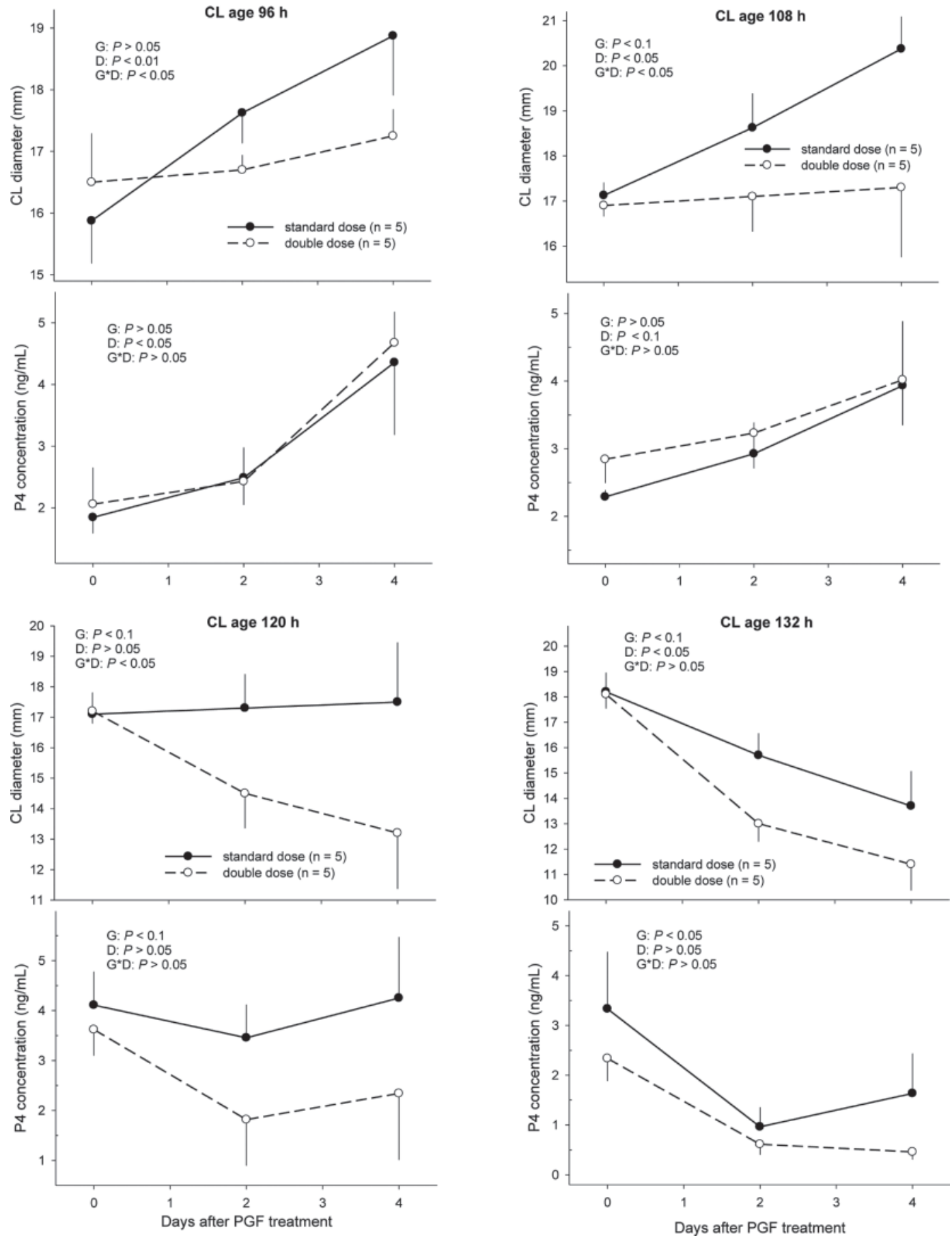

Figure 1. Progesterone (P4) concentration and corpus luteum (CL) diameter. The CL and progesterone data are arranged in 4 groups according to the age of the CL at the time of treatment $(96,108,120$, and $132 \mathrm{~h}$ ). The double and standard doses correspond with 300 and 150 $\mu \mathrm{g}$ of d-cloprostenol, respectively. Within each CL age group, the probabilities for the effect of group (G: double vs. standard dose), day (D: 0, 2 , and $4 \mathrm{~d}$ after treatment), and group by day interaction $\left(\mathrm{G}^{*} \mathrm{D}\right)$ are shown. Error bars represent the standard error of the mean.

For cows treated with double doses of d-cloprostenol, the difference in progesterone concentration between 0 and $2 \mathrm{~d}$ posttreatment and with a CL of 120 and 132 $\mathrm{h}$ old $(1.8 \pm 0.59$ and $1.7 \pm 0.47 \mathrm{ng} / \mathrm{mL}$, respectively $)$ was greater $(P<0.05)$ than that of cows with CL of
108 and $96 \mathrm{~h}$ old $(-0.39 \pm 0.7$ and $-0.31 \pm 0.1 \mathrm{ng} / \mathrm{mL}$, respectively).

In cows with a CL of $132 \mathrm{~h}$ old, the progesterone concentration continued to decrease between 2 and $4 \mathrm{~d}$ after a treatment with the double dose, but not in cows 
Table 2. Effect of corpus luteum (CL) age and d-cloprostenol (d-CLO) dose on rate of progesterone (P4) decrease over time (values presented as mean \pm SEM) ${ }^{1}$

\begin{tabular}{|c|c|c|c|c|c|}
\hline $\begin{array}{l}\text { CL age } \\
\text { (h) }\end{array}$ & $\begin{array}{l}\text { d-CLO } \\
\text { dose }\end{array}$ & $\begin{array}{c}\text { P4: } 0-2 \mathrm{~d} \\
\text { (ng/mL) }\end{array}$ & $P$-value & $\begin{array}{c}\text { P4: 2-4 d } \\
\text { (ng/mL) }\end{array}$ & $P$-value \\
\hline 96 & $\begin{array}{l}\text { Standard } \\
\text { Double }\end{array}$ & $\begin{array}{l}-0.6 \pm 0.3 \\
-0.3 \pm 0.1\end{array}$ & NS & $\begin{array}{l}-1.8 \pm 0.8 \\
-1.9 \pm 0.4\end{array}$ & NS \\
\hline 108 & $\begin{array}{l}\text { Standard } \\
\text { Double }\end{array}$ & $\begin{array}{l}-0.6 \pm 0.5 \\
-0.4 \pm 0.7\end{array}$ & NS & $\begin{array}{l}-1.0 \pm 1.1 \\
-0.5 \pm 1.1\end{array}$ & NS \\
\hline 120 & $\begin{array}{l}\text { Standard } \\
\text { Double }\end{array}$ & $\begin{array}{l}0.6 \pm 0.9 \\
1.8 \pm 0.6\end{array}$ & NS & $\begin{array}{l}-0.8 \pm 0.7 \\
-0.2 \pm 0.6\end{array}$ & NS \\
\hline 132 & $\begin{array}{l}\text { Standard } \\
\text { Double }\end{array}$ & $\begin{array}{l}1.9 \pm 0.6 \\
1.7 \pm 0.5\end{array}$ & NS & $\begin{array}{r}-0.6 \pm 0.4 \\
0.2 \pm 0.1\end{array}$ & 0.09 \\
\hline
\end{tabular}

${ }^{1}$ The CL groups refer to the age of the CL in hours at the time of treatment with a double $(300 \mu \mathrm{g})$ or standard $(150 \mu \mathrm{g})$ dose of D-CLO. P4: 0-2 d: difference in P4 concentration between just before and $2 \mathrm{~d}$ after treatment; P4: 2-4 d: difference in P4 concentration between 2 and $4 \mathrm{~d}$ after treatment. Within the 132-h CL group, the rate of $\mathrm{P} 4$ decrease between 2 and $4 \mathrm{~d}$ after treatment tended $(P=0.09)$ to be greater in cows treated with the double dose than in cows treated with the standard dose.

treated with the standard dose (mean difference in progesterone concentration between 2 and $4 \mathrm{~d}$ posttreatment of $0.2 \pm 0.1$ and $-0.6 \pm 0.4 \mathrm{ng} / \mathrm{mL}$ for double and standard dose groups, respectively; $P=0.09$; Table 2 ).

\section{DISCUSSION}

The main hypothesis tested that a larger dose of d-cloprostenol would induce a greater decrease in progesterone concentration and luteal diameter 2 and $4 \mathrm{~d}$ after treatment cannot be accepted at all levels of CL age. The larger dose $(300 \mu \mathrm{g})$ of d-cloprostenol was superior to the standard dose $(150 \mu \mathrm{g})$ in terms of reducing progesterone concentration within $4 \mathrm{~d}$ of treatment, only in cows with a CL aged between 108 and $132 \mathrm{~h} \mathrm{(4.5} \mathrm{and} 5.5 \mathrm{~d})$ but not earlier. A 12-h gap in the CL age was sufficient to influence whether the dose of d-cloprostenol had an effect on the percentage of cows with full luteolysis. Therefore, the main strengths of this study were the crossover design with each cow acting as her own control for the main effects of dose and the timely calculation of the CL age (detection of ovulation every $12 \mathrm{~h}$ ). This allowed having groups of cows with relatively homogenous CL ages (between 0 and $12 \mathrm{~h}$ difference). This, in part overcame the expected individual variation within groups resultant from their relatively small sample size.

It appears that the effect of dose on progesterone concentration becomes more apparent as the CL gets older: the double dose had no effect in cows with a CL aged between 96 and $108 \mathrm{~h}$; this became a tendency in $120 \mathrm{~h}$ and finally had a significant effect when the CL was $132 \mathrm{~h}$ old. This finding may have clinical implications, as the cows enrolled in an Ovsynch protocol have a CL aged between 132 and $144 \mathrm{~h}$ at the time of the $\mathrm{PGF}_{2 \alpha}$ treatment (Pursley et al., 1995). Along these lines, a large field study with lactating dairy cows in- volving Ovsynch-based synchronization programs with different doses of a luteolytic agent should be carried out. Then, it would be possible to elucidate whether increasing the dose of $\mathrm{PGF}_{2 \alpha}$ is beneficial to achieve full luteolysis in a greater proportion of cows and so improve pregnancy rates (Souza et al., 2007; Martins et al., 2011).

The natural resistance of CL to exogenously induced luteolysis during early diestrus has been widely studied in ruminants (Tsai and Wiltbank, 1997; Tsai and Wiltbank, 1998; Skarzynski and Okuda, 1999; Mamluk et al., 1999; Levy et al., 2000; Sayre et al., 2000; Silva et al., 2000) and yet, it is not completely understood. Possible explanations are reduced availability of endothelin-1 (Levy et al., 2000) and increased availability of prostaglandin dehydrogenase (Silva et al., 2000) in early CL compared with mature CL. Endothelin-1 is a proteinaceous vasoconstrictor and steroidogenic cell modulator produced by endothelial cells in response to $\mathrm{PGF}_{2 \alpha}$ that alters progesterone production in cattle (Girsh et al., 1996), whereas prostaglandin dehydrogenase metabolizes $\mathrm{PGF}_{2 \alpha}$ to its inactive form, 15-keto$\mathrm{PGF}_{2 \alpha}$ in ewes (Silva et al., 2000). It is possible that providing a higher dose of exogenous $\mathrm{PGF}_{2 \alpha}$ would override to some extent the antiluteolytic effect resultant from the increased availability of prostaglandin dehydrogenase and reduced concentration of ET-1 in the early CL.

The results of a similar study in mares (CuervoArango and Newcombe, 2011) also showed a significant effect of d,l-cloprostenol dose on the percentage of mares with full luteolysis when it was administered at different stages of early diestrus. The difference became more apparent as the mares' CL became older. In the latter study, 3 doses of d,l-cloprostenol were attempted: 250 (standard), 500, and $750 \mu \mathrm{g}$. The double dose induced a greater percentage of mares with full luteolysis 
than did the standard dose but it was similar to that induced with $750 \mu \mathrm{g}$. This effect was only significant in mares with CL aged 96 to $104 \mathrm{~h}$, but not earlier. Therefore, it seems that a threshold also exists upon which an increase in d-cloprostenol dosage does not result in an equivalent luteolytic effect.

A recent study (Stevenson and Phatak, 2010), showed a slight difference between dinoprost and d,l-cloprostenol in terms of inducing full luteolysis in lactating dairy cows (91.3 and 86.6\%, respectively). Although, the luteolytic agents were administered as part of a standard Ovsynch protocol (CL ages between 132 and $144 \mathrm{~h}$ ), it should be taken into account that the type of compound used might also influence the outcome of luteolysis in earlier stages of diestrus. Along those lines, $50 \mathrm{mg}$ of dinoprost induced a 50\% (2/4) incidence of full luteolysis in cows treated $108 \mathrm{~h}$ postovulation $(\mathrm{Cu}-$ ervo-Arango et al., 2011). This seems superior to the full luteolysis rate $(20 \%)$ achieved with d-cloprostenol at the same interval postovulation in the current study.

The CL morphology seemed to be affected by the dose of d-cloprostenol to a greater extent and at an earlier stage than its functionality. The diameter of the CL and its ability to secret progesterone do not always correlate well (Herzog et al., 2010). In a recent study (Cuervo-Arango et al., 2011), the CL diameter was reduced to a greater extent and for longer than the progesterone concentration in cows with $\mathrm{PGF}_{2 \alpha}$-induced partial luteolysis compared with nontreated cows.

The reason why the interval between treatment and ovulation in cows treated with double dose was shorter than that of cows treated with the standard dose is unknown. A possible explanation might be that the greater reduction in progesterone concentration, resultant from the larger dose, allowed a more rapid increase in $\mathrm{LH}$ with the subsequent advance in follicular maturation and ovulation. The negative effect that progesterone exerts on LH has been shown (Hannan et al., 2010).

\section{CONCLUSIONS}

Treatment with double dose of d-cloprostenol (300 $\mu \mathrm{g})$ induced a greater proportion of full luteolysis in cows with a CL aged 120 to $132 \mathrm{~h}$ than the standard dose $(150 \mu \mathrm{g})$. This effect was not apparent in cows with earlier CL. The CL diameter tended to be smaller in cows after treatment with double dose when they had a CL of 108 to $132 \mathrm{~h}$ old. A difference as little as $12 \mathrm{~h}$ in the CL age was sufficient to influence the effect of d-cloprostenol dose on the CL morphology and functionality. Cows treated with double dose of d-cloprostenol ovulated a day earlier than cows treated with the standard dose.

\section{ACKNOWLEDGMENTS}

This study was funded by the Universidad CEU Cardenal Herrera (Moncada, Spain; project ref. PRCEU-UCH04/11). This article is intended to be part of the $\mathrm{PhD}$ thesis dissertation of $\mathrm{X}$. Valldecabres-Torres. The authors thank the members of the National Institute for Agricultural Research (INIA, Animal Reproduction Department, Madrid, Spain) for technical assistance with the determination of progesterone concentrations.

\section{REFERENCES}

Beal, W. E., R. A. Milvae, and W. Hansel. 1980. Oestrous cycle length and plasma progesterone concentrations following administration of prostaglandin F-2 $\alpha$ early in the bovine oestrous cycle. J. Reprod. Fertil. 59:393-396.

Beltman, M. E., J. F. Roche, P. Lonergan, N. Forde, and M. A. Crowe. 2009. Evaluation of models to induce low progesterone during the early luteal phase in cattle. Theriogenology 72:986-992.

Brusveen, D. J., A. H. Souza, and M. C. Wiltbank. 2009. Effects of additional prostaglandin $\mathrm{F}_{2 \alpha}$ and estradiol-17 $\beta$ during Ovsynch in lactating dairy cows. J. Dairy Sci. 92:1412-1422.

Cuervo-Arango, J., E. García-Roselló, A. García-Muñoz, X. Valldecabres-Torres, P. Martínez-Ros, and A. González-Bulnes. 2011. The effect of a single high dose of $\mathrm{PGF}_{2 \alpha}$ administered to dairy cattle 3.5 days after ovulation on luteal function, morphology, and follicular dynamics. Theriogenology 76:1736-1743.

Cuervo-Arango, J., and J. R. Newcombe. 2011. Relationship between dose of cloprostenol and age of corpus luteum on the luteolytic response of early dioestrous mares: A field study. Reprod. Domest. Anim. http://dx.doi.org/10.1111/j.1439-0531.2011.01940.x.

Girsh, E., W. Wang, R. Mamluk, F. Arditi, A. Friedman, and R. A. Milvae. 1996. Regulation of the endothelin-1 expression in the bovine corpus luteum: Elevation by prostaglandin $\mathrm{F}_{2 \alpha}$. Endocrinology 137:5191-5196.

Gümen, A., J. N. Guenther, and M. C. Wiltbank. 2003. Follicular size and response to Ovsynch versus detection of estrus in anovular and ovular lactating dairy cows. J. Dairy Sci. 86:3184-3194.

Hannan, M. A., M. J. Fuenzalida, M. A. Siddiqui, M. Shamsuddin, M. A. Beg, and O. J. Ginther. 2010. Diurnal variation in LH and temporal relationships between oscillations in $\mathrm{LH}$ and progesterone during the luteal phase in heifers. Theriogenology 74:1491-1498.

Henricks, D. M., J. T. Long, J. R. Hill, and J. F. Dickey. 1974. The effect of prostaglandin $\mathrm{F}_{2 \alpha}$ during various stages of the oestrous cycle of beef heifers. J. Reprod. Fertil. 41:113-120.

Herzog, K., M. Brockhan-Lüdemann, M. Kaske, N. Beindorff, V. Paul, H. Niemann, and H. Bollwein. 2010. Luteal blood flow is a more appropriate indicator for luteal function during the bovine estrous cycle than luteal size. Theriogenology 73:691-697.

Levy, N., S. Kobayashi, Z. Roth, D. Wolfenson, and A. Miyamoto 2000. Administration of prostaglandin $F_{2 \alpha}$ during the early bovine luteal phase does not alter the expression of ET-1 and its Type A receptor: A possible cause for corpus luteum refractoriness. Biol. Reprod. 63:377-382

Mamluk, R., N. Levy, B. Rueda, J. S. Davis, and R. Meidan. 1999 Characterization and regulation of type A endothelin receptor gene expression in bovine luteal cell types. Endocrinology 140:2110-2116.

Martins, J. P. N., R. K. Policelli, L. M. Neuder, W. Raphael, and J. R. Pursley. 2011. Effects of cloprostenol sodium at final prostaglandin $\mathrm{F}_{2 \alpha}$ of Ovsynch on complete luteolysis and pregnancy per artificial insemination in lactating dairy cows. J. Dairy Sci. 94:2815-2824.

Moreira, F., C. A. Risco, M. F. Pires, J. D. Ambrose, M. Drost, and W. W. Thatcher. 2000. Use of bovine somatotropin in lactating dairy cows receiving timed artificial insemination. J. Dairy Sci. $83: 1237-1247$. 
Pursley, J. R., M. O. Mee, and M. C. Wiltbank. 1995. Synchronization of ovulation in dairy cows using $\mathrm{PGF}_{2 \alpha}$ and $\mathrm{GnRH}$. Theriogenology 44:915-923.

Rowson, L. E., R. Tervit, and A. Brand. 1972. The use of prostaglandins for synchronization of oestrus in cattle. J. Reprod. Fertil. 29:145.

Sayre, B. L., R. Taft, E. K. Inskeep, and J. Killefer. 2000. Increased expression of insulin-like growth factor binding protein-1 during induced regression of bovine corpora lutea. Biol. Reprod. 63:21-29.

Silva, P. J., J. L. Juengel, M. K. Rollyson, and G. D. Niswender. 2000. Prostaglandin metabolism in the ovine corpus luteum: Catabolism of prostaglandin $\mathrm{F}_{2 \alpha}\left(\mathrm{PGF}_{2 \alpha}\right)$ coincides with resistance of the corpus luteum to $\mathrm{PGF}_{2 \alpha}$. Biol. Reprod. 63:1229-1236.

Skarzynski, D. J., and K. Okuda. 1999. Sensitivity of bovine corpora lutea to prostaglandin $\mathrm{F}_{2 \alpha}$ is dependent on progesterone, oxytocin and prostaglandins. Biol. Reprod. 60:1292-1298.
Souza, A. H., A. Gümen, E. P. Silva, A. P. Cunha, J. N. Guenther, C. M. Peto, D. Z. Caraviello, and M. C. Wiltbank. 2007. Supplementation with estradiol-17 $\beta$ before the last gonadotropin-releasing hormone injection of the Ovsynch protocol in lactating dairy cows. J. Dairy Sci. 90:4623-4634.

Stevenson, J. S., and A. P. Phatak. 2010. Rate of luteolysis and pregnancy in dairy cows after treatment with cloprostenol or dinoprost. Theriogenology 73:1127-1138.

Tsai, S. J., and M. C. Wiltbank. 1997. Prostaglandin $\mathrm{F}_{2 \alpha}$ induces expression of prostaglandin $\mathrm{G} / \mathrm{H}$ synthase-2 in the ovine corpus luteum: A potential positive feedback loop during luteolysis. Biol. Reprod. 57:1016-1022.

Tsai, S. J., and M. C. Wiltbank. 1998. Prostaglandin $\mathrm{F}_{2 \alpha}$ regulates distinct physiological changes in early and mid-cycle bovine corpora lutea. Biol. Reprod. 58:346-352. 